\title{
HUBUNGAN ANTARA KECERDASAN EMOSIONAL DENGAN KETERAMPILAN BERKOMUNIKASI PADA SISWA KELAS XI SMA NEGERI 6 MATARAM TAHUN PELAJARAN 2021/2022
}

\author{
Delta Septya Rahayu' ${ }^{1}$, dan Nurul Iman ${ }^{2}$ \\ ${ }^{1,2}$ Program Studi Bimbingan dan Konseling, Fakultas Ilmu Pendidikan dan Psikologi Universitas \\ Pendidikan Mandalika \\ Email: nuruliman@undikma.ac.id
}

\begin{abstract}
Abstrak: Emosional adalah kecakapan utama, suatu kemampuan didalam memantau perasaaan diri sendiri dan perasaan orang lain serta menggunakan informasi untuk mengarahkan pikiran dan tindakan. Kecerdasan emosional adalah merupakan kemampuan untuk memantau perasaan diri sendiri dan orang lain agar mampu mengarahkna pikiran dan tindakan sehingga menghasilkan perilaku yang baik. Berkomunikasi merupakan sarana untuk berinteraksi antara individu satu dengan individu lainnya. Keberhasilan dalam berkomunikasi sangat ditentukan oleh kemampuan berkomunikasi seseorang menjadi bagus dan bermakna, maka untuk mengasah kemampuan tersebut dapat melalui proses pembelajaran.rumusan masalah dalam penelitian ini adalah "Apakah ada Hubungan Antara Kecerdasan Emosional Dengan Keterampilan Berkomunikasi Siswa di SMA Negeri 6 Mataram Tahun Pelajaran 2021/2022?". Tujuan dalam penelitian ini adalah "Untuk mengetahui Hubungan Antara Kecerdasan Emosional dengan Keterampilan Berkomunikasi pada Siswa SMA Negeri 6 Mataram Tahun Pelajaran 2021/2022”. Populasi dalam penelitian ini ada 2 kelas XI IIS 1 dan XI IIS 2 SMA Negeri 6 Mataram yang berjumlah 378 siswa, sampel yang digunakan berjumlah 69 siswa. Tehnik pengambilan sampel menggunakan purposive sampling Dalam penelitian ini metode pengumpulan data yang digunakan adalah metode angket sebagai motode pokok, observasi, dokumentasi, dan wawancara sebagai metode pelengkap. Analisis data menggunakan rumus product moment. Bedasarkan hasil analisis data dengan taraf signifikan 5\% maka diperoleh hasil penelitian yaitu nilai rxy lebih besar dari nilai $r$ product moment (rxy $0.992>$ r product moment 0,224). Kenyataan ini menunjukkan bahwa nilai rxy yang diperoleh dari hasil analisis data dapat disimpulkan bahwa: Ada Hubungan Antara Kecerdasan Emosional dengan Keterampilan Berkomunikasi pada Siswa XI SMA Negeri 6 Mataram Tahun Pelajaran 2021/202, dengan demikian dalam penelitian ini dinyatakan Signifikan.
\end{abstract}

Kata Kunci: Kecerdasan Emosional dan Keterampilan Berkomunikasi

\section{PENDAHULUAN}

Manusia sesuai dengan kodratnya adalah mahluk sosial atau mahluk bermasyarakat. Manusia sebagai mahluk sosial, hidup bersama dengan manusia lainnya karena di dalam dirinya terdapat dorongan dan kebutuhan untuk berhubungan atau berintraksi dengan indvidu lainnya. Interaksi tersebut dapat berjalan dengan baik apabila masing-masing individu mampu berkomunikasi secara efektif sehingga dari komunikasi tersebut terbentuklah hubungan antar pribadi yang baik.

Hubungan antar pribadi memainkan peran penting dalam membentuk kehidupan sosialnya. Adapun yang seharusnya dapat dilakukan oleh individu agar dapat hidup harmonis dengan individu lainnya adalah dengan mampu berkomunikasi positif, baik secara verbal maupun nonverbal. Setiap individu tergantung kepada individu lainnya dalam hal emosi, pemahaman informasi, dukungan dan berbagai bentuk komunikasi yang mempengaruhi citra dirinya serta membantunya mengenali harapan-harapan orang lain. Salah satu area dalam hubungan antar pribadi yang penting adalah emosi, karena emosi merupakan warna dan musik kehidupan (Prasetya \& Gunawan, 2018). Adapun menurut Santrock (2007) emosi pula yang mengikat orang untuk hidup berdampingan.

Manusia mempunyai kecendrungan untuk menikmati emosi yang positif dan merasa tidak nyaman dengan emosi negatif. Kadang-kadang permasalahan yang muncul juga karena disebabkan oleh intensitas atau cara yang salah dalam mengekspresikan 
emosi, meskipun yang dialami pada hakikatnya benar. Dalam hal ini, emosi sangat berperan penting di dalam kehidupan dan khususnya dalam berintraksi dengan orang lain sehingga diharapkan individu dapat memiliki kecerdasan emosi sebagai wujud pertahanan diri untuk mengarahkan diri kearah yang positif.

Menurut Goleman (1995) kecerdasan emosi adalah kecakapan utama, yang secara mendalam dapat mempengaruhi semua kemampuan lainnya dalam diri individu. Seseorang dikatakan memiliki kecerdasan emosi (emotional intelegence) jika: 1) mampu mengenali emosi diri, 2) mampu mengendalikan emosi diri sesuai dengan situasi dan kondisi, 3) mampu menggunakan emosinya untuk meningkatkan motivasi diri, 4) mampu mengenali emosi orang lain, dan 5) mampu berintraksi positif dengan orang lain (Prasetya \& Gunawan, 2018).

Emosi yang tidak terkontrol bisa dialami siapa saja tidak terkecuali bagi siswa SMA. Dalam hal ini siswa SMA masih tergolong dalam kategori remaja awal. Masa remaja adalah sepotong masa kehidupan yang penuh dengan "badai dan topan" perasaan yang penuh gejolak dan peka terhadap rangsangan-rangsangan negatif. Menurut Hurlock (2004) secara tradisional masa remaja dianggap sebagai periode "badai dan tekanan", yaitu suatu masa dimana ketegangan emosi meninggi sebagai akibat dari perubahan fisik dan kelenjar. Adapun persiapan diri yang kurang terhadap perubahan yang cepat dan dramatis dapat memicu terjadinya masalah-masalah yang serius.

(Cherniss, 2001) menyatakan bahwa kecerdasan emosi adalah kemampuan untuk melihat dan mengekspresikan emosi, mengasimilasi emosi dalam pikiran, memahami dan bernalar dengan emosi, dan mengatur emosi dalam diri orang lain.

Menurut Davies (Casmini, 2007) menjelaskan bahwa kecerdasan emosi adalah kemampuan seseorang untuk mengendalikan emosi dirinya sendiri dan orang lain, membedakan satu emosi dengan lainnya dan menggunakan informasi tersebut untuk menuntun proses berfikir dan berperilaku seseorang.

Menurut Bar-On (dalam Cherniss, 2001) mendefinisikan kecerdasan emosi dalam susunan pengetahuan, kemampuan emosional dan social yang mem pengaruhi kemam puan untuk mengatasi tuntutan lingkungan, meliputi: 1). Kemampuan untuk mengekspresikan diri, 2). Kemampuan berhubungan dengan orang lain, 3). Kemampuan untuk menghadapi emosi dan mengendalikan dorongan seseorang, 4). Kemampuan beradaptasi dengan perubahan untuk memecahkan masalah yang bersifat pribadi atau social. Motivasi menurut Myres dalam (Lusiawati, 2013) adalah suatu kebutuhan atau keinginan yang dapat memberi kekuatan dan mengarahkan tingkah laku. Permasalahan yang sering kali terjadi dan di alami oleh siswa sekolah menegah atas adalah masih banyaknya siswa yang tidak mampu mengelola emosinya dengan baik sehingga menyebabkan mereka sering marah sambil mengumpat dengan menggunakan bahasa yang kasar kepada temannya di sekolah. Selain itu walau pun tidak dalam keadaan marah, sering juga dijumpai siswa yang masih menggunakan kata-kata kasar atau tidak pantas di dalam berkomunikasi dengan teman dan guru. Dalam hal ini perilaku tersebut dianggap tidak pantas dan layak untuk dilakukan oleh seorang siswa di sekolah. Menurut Robbins \& Jones (dalam Murwani \& Istichomah, 2009) komunikasi adalah suatu transaksi, proses simbolik yang menghendaki orang-orang mengatur lingkungannya dengan membangun hubungan antar sesama manusia melalui pertukaran informasi untuk menguatkan sikap dan tingkah laku orang lain serta mengubah sikap dan tingkah laku tersebut. Adapun menurut Berelson \& Stainer (dalam Nurhasanah, 2010) komunikasi adalah proses penyampaian informasi, gagasan, emosi, keahlian dan 
lain-lain melalui penggunaan simbol-simbol seperti kata-kata, gambar-gambar, angkaangka dan lain-lain.

Pendapat lain oleh Sardiman (2011) mengartikan bahwa istilah komunikasi yang nerasal dari perkataan 'communicare' berarti 'berpartisipasi', 'memberitahukan', 'menjadi milik bersama'. Secara konseptual arti komunikasi itu sendiri sudah mengundang pengertian-pengertian menyebarkan berita, pengetahuan, pikiran-pikiran, dan nilai-nilai dengan maksud menggugah partisipasi, mempermudah untuk memberitahukan kepada teman, dan selanjutnya akan mencapai persetujuan mengenai sesuatu pokok ataupun masalah yang merupakan kepentingan bersama.

Adapun menurut Abdul Aziz Wahab (2009) bahwa teori berkomunikasi berpengaruh pada teori belajar, hal ini dapat dibuktikan bahwa untuk mengajar yang baik memerlukan komunikasi yang baik pula.

Jadi komunikasi secara umum adalah suatu proses pembentukkan, penyampaian, penerimaan dan pengolahan pesan yang terjadi di dalam diri seseorang dan atau diantara dua atau lebih dengan tujuan tertentu. Komunikasi dikatakan berhasil jika memiliki beberapa aspek yaitu: a) perubahan sikap, b) perubahan pendapat, c) perubahan prilaku, dan d) perubahan sosia 1 (Murwani \& Istichomah, 2009).

Salah satu perubahan siswa yang menonjol pada masa remaja adalah perubahan emosional peserta didik. Hal tersebut merupakan hal yang alamiah dan wajar namun perlu dikendalikan dan diawasi, karena setiap individu memiliki kecerdasan emosional yang bervariasi. Beberapa permasalahan mengenai kecerdasan emosi yang terkait dengan kemampuan siswa dalam berkomunikasi adalah banyaknya siswa yang tidak berani mengutarakan apa yang menjadi kesulitannya dalam proses belajar mengajar di dalam kelas. Adapun dalam berkomunikasi dengan orang yang lebih dewasa atau dengan guru masih banyak siswa yang tidak bisa berbicara dengan sopan dalam artian belum bisa menggunakan intonasi suara yang sesuai. Adapun lebih parahnya lagi masih banyak siswa yang menggunakan kata-kata kasar dalam bergaul dengan teman sebayanya. Permasalahan-permasalah tersebut banyak terjadi di lingkungan SMA Negeri 6 Mataram.

\section{METODE PENELITIAN}

Metode yang digunakan dalam penelitian ini adalah metode eksperimen dengan korelasi product moment. Populasi penelitian dapat mengacu pada keseluruhan individu yang berada pada tempat dan waktu yang sama (wilayah) yang kemudian akan menjadi objek penelitian untuk mendapatkan data yang diperlukan. Adapun populasi penelitian ini adalah seluruh siswa kelas XI SMAN 6 Mataram Tahun Pelajaran 2021/2022 yang berjumlah 378 siswa.

Metode penelitian dijelaskan bahwa rancangan pada dasarnya merupakan penggambaran mengenai keseluruhan aktivitas peneliti selama kerja penelitian mulai dan persiapan sampai deangan pelaksanaan penelitian. Dilihat dari jenis penelitian, maka penelitian ini tergolong penelitian kuantitatif (penelitian statistik) yang diangkakan/skoring (Sugiyono, 2012).

Dalam peneliti ini terdapat dua variabel yakni variabel independen dan variabel dependen. Variabel independen adalah variabel yang nilainya menetukan variabel lain. Suatu kegiatan stimulus yang dimana populasi oleh peneliti menciptakan suatu dampak pada variabel independen. Variabel independen biasanya dimanipulasi, diamati, dan 
diukur untuk diketahui hubungannya atau pengaruh terhadap variabel lainnya. Pada penelitian ini yang merupakan variabel independen adalah kecerdasan emosional.

Terkait dengan judul penelitian ini, maka teknik pengambilan sampel yang berdasarkan pada pertimbangan dan tujuan tertentu (proposive sampling). Proposive sampling adalah teknik penentuan sampel dengan pertimbangan tertentu (Sugiyono, 2014). Kaitannya dengan penelitian ini yang menjadi sampel adalah Siswa kelas XI SMA Negeri 6 Mataram Tahun Pelajaran 2021/2022 yang berjumlah 69 orang siswa, yang terdiri dari 2 kelas dengan penjabaran sampel.

Sedangkan variabel dependen adalah variabel yang nilainya ditentukan oleh variabel lainnya. Dalam ilmu tingkah laku, variabel tergantung adalah aspek tingkah laku yang diamati dari suatu organisme yang dikenai stimulus. Dengan kata lain, variabel terikat adalah faktor yang diamati dan diukur untuk menentukan ada tidaknya hubungan atau pengaruh dari variable independen.

Instrumen penelitian adalah suatu alat ukur. Dengan instrument ini dapat dikumpulkan data sebagai alat untuk menyatakan besaran serta lebih kurangnya dalam bentuk kuantitatif dan kualitatif. Untuk mengetahui data tentang adanya korelasi antara kecerdasan emosi dengan kemampuan berkomunikasi pada siswa kelas XI di SMA Negeri 6 Mataram tahun pelajaran 2021/2022 digunakan instrument berupa angket, dalam bentuk tertutup dan secara langsung dimana responden (subyek) penelitian tinggal memilih jawaban yang sesuai dengan keadaan dirinya.

\section{HASIL PENELITIAN DAN PEMBAHASAN}

Adapun data yang dikumpulkan dari hasil angket siswa sebagai mana pada tabulasi data penilaian skor angket sesuai dengan tabel. Adapun rekapitulasi hasil skor angket tersebut. Data yang dikumpulkan melalui metode angket dalam penelitian ini adalah data tentang kecerdasan emosional dan keterampilan berkomunikasi.Dalam penyebaran dan pengumpulan angket ini peneliti dibantu oleh guru BK, dan siswa-siswa itu sendiri. Dari hasil pengisiian angket yang terdapat pada tabel tersebut, ada variabel terikat mengenai kecerdasaan emosional yang terdiri dari beberapa indikator yang merupakan aspek utama kecerdasaan emosional dan masing-masing indikator tersebut mempunyai sub indikator yang berbeda-beda. Adapun jenis-jenis indikator dan sub indicator dari data pengisiian angket tersebut adalah: indikator persepsi memiliki 5 sub indikator yaitu, mengenali emosi, mengendalikan emosi, motivasi diri, empati ,berinteraksi positif. Indikator intruksi memiliki 5 sub indikator yaitu, menyadari dan memahami, individu mampu terhubung dengan emosi dan pikirannya, kesadaran diri, menangani perasaan,kemampuan individu.

Sedangkan variabel terikat mengenai keterampilan berkomunikasi yang terdiri dari beberapa indikator dan masing-masing indikator tersebut memiliki sub indikator yang berbeda-beda. Adapun jenis-jenis indikator dan sub indikator dari data pengisiian angket tersebut: indikator tertekan memiliki 4 sub indikator yaitu, perubahan sikap, perubahan pendapat atau gagasan, perubahan perilaku, perubahan social. Populasi dalam penelitian ini adalah siswa SMA kelas XI yang terdiri dari keseluruhan jumlahnya (378 siswa) dengan sampel penelitian sebanyak 2 kelas (69 siswa). Dalam hal ini, purposive sampling adalah "teknik untuk menentukan sampel penelitian dengan beberapa pertimbangan tertentu yang bertujuan agar data yang diperoleh bisa lebih representatif' (Sugiyono, 2014). Hasil dari penelitian ini menunjukkan bahwa terdapat hubungan positif antara kecerdasan emosional dan komunikasi interpersonal. Kecerdasan emosional memberikan sumbangan efektif sebesar $46 \%$ terhadap 
komunikasi interpersonal. Dengan instrument ini dapat dikumpulkan data sebagai alat ukur menyatakan besaran serta lebih kurangnya dalam bentuk kuantitatif dan kualitatif.

\begin{tabular}{|c|c|c|c|}
\hline No & Inisial Siswa & $\begin{array}{c}\text { Skor Kecerdasan } \\
\text { Emosional }\end{array}$ & $\begin{array}{c}\text { Keterampilan } \\
\text { Berkomunikasi }\end{array}$ \\
\hline$(1)$ & $(2)$ & $(3)$ & $(4)$ \\
\hline 1 & AAS & 58 & 56 \\
\hline 2 & A & 55 & 52 \\
\hline 3 & AF & 59 & 55 \\
\hline 4 & BDR & 49 & 46 \\
\hline 5 & IGBYPW & 53 & 45 \\
\hline 6 & IKY & 59 & 44 \\
\hline 7 & IKJK & 55 & 52 \\
\hline 8 & IMBK & 53 & 54 \\
\hline 9 & IMRP & 45 & 52 \\
\hline 10 & IMY & 55 & 54 \\
\hline
\end{tabular}

Dari tabel kerja tersebut di atas, maka dapat dihitung nilai rumus korelasi product moment sebagai berikut:

$$
\begin{aligned}
r_{x y} & =\frac{\sum_{x y}}{\sqrt{\left(\Sigma x^{2}\right)\left(\sum y^{2}\right)}} \\
r_{x y} & =\frac{70.023}{\sqrt{(70.410)(70.766)}} \\
r_{x y} & =\frac{70.023}{\sqrt{4982.634}} \\
r_{x y} & =\frac{70.023}{70.587} \\
r_{x y} & =0,992
\end{aligned}
$$

Berdasarkan hasil perhitungan rxy diperoleh dalam penelitian ini adalah 0.992 sedangkan nilai $r_{\text {tabel }}$ dengan taraf signifikan $5 \%$ dan $\mathrm{N}=69$ adalah 0.244 yang berarti $r_{\text {hitung }}>r_{\text {tabel }}(0.992>0.244)$. Kenyataan ini menunjukkan bahwa nilai Korelasi Product Moment yang diperoleh dalam penelitian ini adalah lebih besar dari pada nilai $r_{\text {tabel, }}$

Berdasarkan hasil perhitungan dari $r_{\text {hitung }}$, maka korelasi product moment yang ditemukan sebesar 0,992 termasuk dalam kategori sangat kuat. Jadi kesimpulannya terdapat hubungan yang sangat kuat antara kecerdasan emosional dengan keterampilan berkomunikasi dan hubungan ini hanya berlaku untuk sampel dalam penelitian ini. Hasil analisis data yang diperoleh pada $r_{\text {hitung }}=0,992$ yang selanjutnya dikonsultasikan dengan $r_{\text {tabel }}$ pada taraf signifikan $5 \%$ dan $\mathrm{N}=69$ diperoleh $r_{\text {tabel }}=0,244$, hasil ini menunjukkan bahwa $r_{\text {hitung }}>r_{\text {tabel }}$. Maka dapat dikemukakan bahwa hipotesis nihil (Ho) ditolak yaitu Tidak ada hubungan antara kecerdasan emosional dengan keterampilan berkomunikasi siswa kelas XI di SMA Negeri 6 Mataram Tahun Pelajaran 2021/2022dan hipotesis alternatif (Ha) diterima yaitu:ada hubungan antara kecerdasan emosional dengan keterampilan berkomunikasi siswa kelas XI di SMA Negeri 6 
Mataram Tahun Pelajaran 2021/2022, sehingga dapat disimpulkan bahwa hasil penelitian ini Signifikan.

\section{SARAN}

1. Kepala sekolah, memberikan masukan kepada guru agar lebih kreatif dan inovatif di dalam upaya membantu meningkatkan kecerdasan emosional siswa sehingga keterampilan berkomunikasinya menjadi meningkat.

2. Guru bimbingan konseling, hendaknya lebih mengoptimalkan layanan bimbingan dan konseling kepada para siswa terutama dalam mengatasi masalah mengelola emosi dan berkomunikasi.

3. Bagi siswa, hendaknya memanfaatkan kecerdasan emosi yang dimiliki untuk meningkatkan kemampuannya di dalam berkomunikasi.

4. Peneliti lain, diharapkan dapat mengadakan penelitian yang lebih mendalam dan lebih luas khususnya mengenai hal-hal yang belum diungkap dalam penelitian ini.

\section{DAFTAR PUSTAKA}

Astuti, H., 2005, Psikologi perkembangan masa dewasa, Surabaya: Usaha Nasional.

A.M. S ardiman. 2011. Interaksi dan Motivasi Belajar Mengajar. Jakarta: PT. Rajagrafindo.

Murwani, A., \& Istichomah. (2009). Komunikasi Untuk Terapeutik Panduan Bagi Perawat. Yogyakarta: Fitramaya.

Santrock, J.W. (2007). Child Development, Eleven Edition. University of Texas, Dallas. McGraw Hill Companies, Inc.

Suharsimi, A. (2008). Prosedur penelitian suatu pendekatan praktek (Edisirevisi VI). Jakarta: Rineka Cipta. 